\title{
Islamic Cultural Center Jakarta: A Unique Type of Iranian Public Diplomacy
}

\author{
Mohamad Rezky Utama', Yon Machmudi ${ }^{2}$, Muhamad Syauqillah ${ }^{3}$ \\ \{1utamamohamad@gmail.com, ${ }^{2}$ machmudi@ui.ac.id, ${ }^{3}$ muhamadsyauqillah@ui.ac.id $\}$ \\ ${ }^{1,2,3}$ School of Strategic and Global Studies, Universitas Indonesia, Indonesia
}

\begin{abstract}
Researches about relations between public diplomacy and Shiism are undoubtedly low in numbers, compared to many other researches about diplomacy, particularly in its correlation with religion. The Islamic Republic of Iran is one of sovereign states that exercise faith public diplomacy. In Indonesia, they have opened the Islamic Cultural Center as their form of public diplomacy aimed to Indonesian public. The cultural diplomacy theory, with faith diplomacy and new public-diplomacy concept are applicable in examining this type of diplomacy. As the result of a careful observation, in-depth interview with snowball sampling method, literature reviews and theory-based analysis, some findings of this research are: the organisational structure of ICC is directly under the Office of Supreme Leader of Iran (or commonly known as the office of Vilayat-e Faqih) in accordance with Iranian Constitution; Twelver Shiism is related with ICC through its facilities, Shiite educational activities, and religious festivities; in spite of its structural position, ICC function as the facilitator between Iran - with its Shiisim - and Indonesian diverse society, and particularly Indonesian Shia Community. This research is a Qualitative Research.
\end{abstract}

Keywords: Iran, Public, Diplomacy, ICC

\section{INTRODUCTION}

The Islamic Republic of Iran is a sovereign state in the Middle East that possesses a distinct religious and political structure. The study of Iranian Islam and how they manage to introduce it to the world is undoubtedly less attractive to the Middle-East issues researchers, compared to Israeli-Palestinian or terrorism issues. One of Iran's ways to promote its country is through public diplomacy. This paper will provide a concise analysis on Iranian public diplomacy in Indonesia by the form of cultural centre. The Islamic Cultural Center Jakarta, as it is named, promotes the Iranian Shiite Islamic culture. Therefore, the identity politics play a big role for Iranian mission in Indonesia that aimed to create a positive image of Iran.

Numbers of research on Middle-Eastern public diplomacy and religion is still relatively small in number. In Universitas Indonesia alone, there are only five scientific articles discussing 'Middle East diplomacy', and none if 'public' is added. In the other hand, dozens of scientific articles are found, if 'ISIS' is typed in the search section (Universitas Indonesia Library, 2008). Meanwhile, understanding public diplomacy as a new type of diplomacy is 
necessary in a globalised world. And the use of technology and religion in public diplomacy is also a new phenomenon in this era.

Moreover, Iran, as mentioned before, has a distinct form of government. Unlike a common form of democracy, Iran has Vilayat-e Faqih. Vilayat-e Faqih is a concept of governance manifested from Shiite political ideology. This particular Imamate concept has eventually existed within the Shiite political thoughts. The Shiites see the Ali and his descendents are the rightful successors of the Prophet Muhammad. After the disappearance of the Twelfth Imam, according to the Shiite belief, Muslims must wait for his reappearance before the world ends. In Ayatollah Khomeini point of view, the Muslims still has to be led by someone who is righteous and rightful, until the resurgence of the twelfth Imam. Therefore, he put foreward this Idea of Vilayat-e Faqih, after the Iranian Revolution of 1979 (Riza Sihbudi, 1996: 124130). This Vilayat-e Faqih is soon manifested through the formal institution, the Office of Supreme Leader (Daftar-e Rahbari).

The Islamic Cultural Center in Jakarta differs structurally with common public diplomacies. As a new type of diplomacy, many public diplomacy institutions such as @america, British Council, or Institut Français d'Indonesie, are under the respective embassy along with its management. Whereas, in spite of its structural position as subordinate of the Embassy of Iran, the management is managed directly by the Office of Supreme Leader.

Despite of intriguing yet strong management structure, numerous Indonesian Sunnis or even Shiites have a minimum knowledge about the existence of this institution. During the research, there are only around 20 people who visit in a day. But the number can be increased during a celebration or commemoration events up to thousands. This situation has not changed much since 2013, when Zulkarnain Fadli, a researcher from Universitas Islam Negeri Syarif Hidayatullah Jakarta conducted a research about the tutorship in the institution. (Fadli, 2013).

After that, as an institution aimed for the introduction of Iran to Indonesia, ICC correlates with the Shiite communities in Indonesia. They frequently hold Shiite related events. This events are varied, from Friday Prayer to the commemoration of the Imams and their families. These situations may raise three questions to be explained further i.e. Why is ICC managed by the Office of Supreme Leader? How is the Shiism used as an instrument of Public Diplomacy in ICC? How is the relation between ICC and Shiite Community in Jakarta?

\section{THEORETICAL FRAMEWORK AND METHODS}

To explain the Islamic Cultural Center, a type of diplomacy that would be used is the new public diplomacy. The new public diplomacy is a type of diplomacy that recognises both state and non-state actors, modern technology environment (satellite, internet, etc.), blur domestic and international boundaries, internet branding, branding through soft power, an actor as the facilitator of information exchange, and aimed for relationship building (Cull, 2009:14). Moreover, public diplomacy has no standard structure. According to Nicholas Cull, many public diplomacy elements are not new inventions, only the term that is new (Cull, 2009:17).

Next, religion was predicted will be abandoned when science is more advanced (Loskota, 2013:10-11). However, religion is not abandoned but becoming more significant in politics. And after 1980s, religion has begun to be used as one of diplomatic element. The concept of religion in diplomacy was explained by Mohammed el-Nawawy:

"In a public diplomacy context, faith diplomacy can be defined as 'the use of religion to communicate with the global politics.' It incorporates 'religious insights and influence with traditional diplomatic practices (realpolitic) for the purpose of peacemaking." (el-Nawawy, 2013: 113) 
According to Nicholas Cull, cultural diplomacy is "an actor's attempt to manage the international environment through making its cultural resources and achievements known overseas and/or facilitating cultural transmission abroad" (Cull, 2009:19). Cultural diplomacy has long-term, outward, and in form of a cultural centre and/or a library.

The research is a qualitative research. A qualitative research uses appropriate methods to explain social and humanitarian phenomena (Creswell, 2010:92). Within this qualitative research, there are three techniques of data collection: observation, in-depth interview, and literature studies. Firstly, Observation in a qualitative research is aimed to understand the situation and it is a right method to examine unfamiliar issues or places (McKechnie, 2008: 573-754). Secondly, an interview involves an interviewer who asks questions to the interviewee as the respondent (Brinkmann, 2008: 470). In this research in-depth interview was used because it requires longer and deeper answer to understand a problem (Cook, 2018:423). In addition, snowball sampling that rely in one interviewee and ask his recommendation for more interviewees and so on is effective for sensitive issues to avoid rejections from the interviewees. Lastly, Literature study is used by studying the written resources as references (Race, 2008: 487-489). The study is used to compliment the uncovered aspects to be explained further.

\section{FINDINGS}

\subsection{An Iranian Public Diplomacy Institution}

ICC is a public diplomacy institution with distinct identity and characteristics. This institution was officially opened in 2000. Structurally, Islamic Cultural Center is a subordinate of Cultural Attaché of the Embassy of the Islamic Republic of Iran. Which means, legally, the institution is under the authority of Iranian Embassy as IFI under French, and Goethe under German. Yet, in its managerial affairs, recruitment system and employer's development, ICC is directly managed by the authority of the Office of Supreme Leader. This management system is not unreasonable. In order to understand the context of ICC, the discussion about governmental structure of Iran must be understood beforehand.

First, the authority of the Supreme Leader is constituted in the Constitution of the Islamic Republi of Iran Article 107, 109, 110, and 111. Article 107 explains about the election system of the Supreme Leader. The leader was elected by the Assembly of Experts, that the members are voted through general elections. The elected Supreme Leader will be on the position of Wilayat-e Faqih (the Guardian of Jurists) while maintaining the same degree before the Law. After that, article 109 states about qualification criteria of a Supreme Leader. Somebody who becomes a supreme leader must be educated in religious knowledge, fair and pious, and rightly politics and social intelligence, wisdom, courage, administratively capable, and sufficient capability to be a leader. The responsibilities and authorities of a leader is explained and defined in article 110. Some of the duties and authorities are in every Islamic-related policy in Iran. Not only that, the Iranian constitution also regulates the dismissal and resignation of a leader in article 111. (Office Supreme Leader, 2018)

In addition, the authority of the executive is not insubstantial. The duties and authorities of the executive are regulated through article 60, 113, and 131. In article 60, the function of the executive, excluding affairs that directly become Supreme Leader's jurisdiction in accordance with the national constitution, is executed by the president and the ministers. The president is the second highest position right after the Supreme Leader as stated in article 113. His 
responsibilities are: implementing constitution and acting as the head of executive, except in affairs that directly related to the (Office of Supreme Leader). And the dismissal, death, and resignation are regulated in article 131 (Office of Supreme Leader, 2018)

The President must appoint his ministers which one of them is the minister of foreign affairs. This appointment is based on Iranian constitution article 133 which states that the jurisdiction of a minister is determined by law. The dismissal of a minister can be conducted by the president or according to the parliamentary vote. One of the minister is the minister of foreign affairs who is superordinate of ambassadors. An ambassador is appointed with the recommendation from the minister of foreign affairs and approved by the president. (Islamic Republic of Iran: Ministry of Foreign Affairs, 2017)

The structure of governance above is also characterising the Iranian public diplomacy overseas. Iranian embassy in Indonesia deals with several different affairs. These affairs covers political, economic, cultural, consulate, and press affairs (the Embassy of the Islamic Republic of Iran: Jakarta, 2013). Every affair has its own attaché. One of the attaché is the Attaché of Cultural Affairs is above the Islamic Cultural Center Jakarta. However, in its management, the Islamic Cultural Center I directly managed by the Office of Supreme Leader of Iran. The embassy has no authority on religious affairs includes ICC. ICC's director along with the recruitment is related with the Office of Supreme Leader of Iran, Daftar-e Rahbari. Its director is a mujtahid - somebody who has mastered the Islamic jurisprudence, but has not complete a book to be qualified as marja - who is appointed directly from Iran.

Accprding to Ahmad Hafidh Alkaf, one of cleric in ICC who also acts as public relations of ICC, this scheme of management has been designed since the early establishment of the ICC (Alkaf, 2018). The employer and its director are directly under the guidance of the Office of Supreme Leader, including the budgeting process. So, ICC introduces Iran which is inseparable from Islam. It is also the background why the institution name is "Islamic" instead of "Iranian".

Therefore, the structure and managerial affairs of the ICC is not under one body as many other countries do with their cultural centres. This condition shaped the Iran's Islamic Cultural Center with its own distinctive identity. According to the constitution, ICC is under the Embassy due to its status as a foreign entity in the destination country. This situation allows ICC to have its firm legal basis. However, since the Islamic affairs in the Islamic Republic has been the responsibility of the Supreme Leader, Islamic Cultural Center Jakarta with its aim to introduce Iranian Islamic identity to Indonesian public is absolutely required to be under the management of the Office of the Supreme Leader. In this case, they who understand best about Iranian Shiite Islam have more authority to shape the activities in ICC that aimed for Indonesian public in general.

\subsection{Shiism within the ICC}

It is indisputable that majority of Shiite Islam has been determining Iranian Islamic culture for centuries. In an organisation with a unique structure and managerial system, the major Islamic scholar in Iran, Twelver Shia, is the school which is introduced and celebrated in Islamic Cultural Center. This transfer of culture is considered as public diplomacy. Thus, before going to Shiism in the ICC, there are some key Shiite believes that is also visible in ICC's events and activities.

Firstly, Ghadir Khum and some political constellation during Ali bin Abi Talib administration become the centre of Twelver Shiite historical traditions. They trace their history back to Ghadir Khum. Ghadir Khum is an event where Muhammad appointed Ali bin 
Abi Talib as his successor or the 'imam' of the people. Ghadir Khum is a name of location between Mecca and Medina. According to the Shiite's tradition, the hadith was narrated in front of 150,000 sahabah - people who meet Rasulullah in person (Tim Ahlul Bait Indonesia, 2012:147). However, during the his leadership, Ali was regarded as unfair by not investigating the assassin of Uthman and by replacing Uthman's relatives from their positions in the Caliphate. This resulted some war against Ali which are led by Muawiyah with other sahabah includes Muhammad's wife, Aisha, in the War of the Camel. By the end of this conflict, Hassan ibn Ali ibn Abi Talib were willing to pledge his allegiance to Muawiyah ibn Abi Sufyan as the caliph. But it was not end there, the battle of Karbala is one of the unforgettable even for the Twelver Shiites, due to the assassination of Hussein ibn Ali against Yazid ibn Muawiyah (S.J. Halim, 2012:23-24)

For the Shiite which is the major Islamic Scholar in Iran, Imam is more likely to be inherited directly as Ali ibn Abi Talib was appointed by Muhammad, and Hassan ibn Ali by Ali bin Abi Talib. This tradition is aimed to retain and protect Islamic teachings and leadership. However, the term "Twelver Shia" is a relatively new term which emerged in the 9th Century, when all of Imam came. This point of view is slightly different with Ismailites who believe that there were only seven Imams. (S.J., Halim, 2012: 25)

In Shiite belief, there are twelve imams with the twelfth Imam is hidden and will return at the end of the world. Those imams are: Ali ibn Abi Talib, Hassan ibn Ali (al-Mujtaba), Hussein ibn Ali (Sayyid asy-Syuhada), Ali ibn Hussein (Zainal Abidin), Muhammad ibn Ali (al-Baqir), Ja'far ibn Muhammad (ash-Shadiq), Musa ibn Ja'far (al-Kadzim), Ali ibn Musa (ar-Ridha), Muhammad ibn Ali (at-Taqi), Ali ibn Muhammad (an-Naqi), Hussein ibn Muhammad (al-Askari), Dan Muhammad ibn Hussein (al-Qalam). The twelfth Imam, Muhammad ibn Hussain, is believed to be absent hideously and will return at the end og the time as Imam Mahdi.

Generally, twelver Shiite has five fundamental teachings. The first fundamental is Ma'rifat al-Allah which stands for the knowledge of Allah. The second fundamental is Ma'rifat al-'Adl al-Ilahi which stands for knowledge of divine justness. The third fundamental is Ma'rifat alNubuwah which stands for the knowledge of prophets. The fourth fundamental is Ma'rifat alImamah which stands for the knowledge of the Imamate. And the last fundamental is Ma'rifat al-Ma'ad or the knowledge of eschatology.

In the Islamic Cultural Center, the twelve Shiite Islam is noticeable ubiquitously. This situation is also visible the events in ICC. But the most important of all is the director, a mujtahid, whom was designated as the referee for Shiite community in Indonesia.

In every books of Shiite Jurisprudence, according to Ahmad Hidayat, general secretary of Ahlul Bait Indonesia, the beginning of the book will always talk about marja'-e taqlid - a marja' to be followed - before the chapter of ablutions like the Sunni do (Hidayat, 2018). Moreover, taqlid means "following in issues of jurisprudence by following a jurist.Twelver Shiites believe the every muslim, in conducting his/her deeds, must be according to fatwa opinion in legal affairs - from a mujtahid who he/she follows. (Zadeh, 2017)

Continuing the discussion, Dr. Abdul Majid Hakimelahi as the director of ICC during the time of the research has already gain his status as a mujtahid - not a marja'. According to Hidayat from ABI. The existence of ICC is becoming the place for people ask questions, and religious problems related to the Twelver Shia (Hidayat, 2018). He, Dr. Halimelahi, is not only holding a position as the head of the institution, he is also taking the role and responsibility as the mujtahid by answering questions in ICC's official website and lecturing the classes of religious knowledge. 
From the observation, Islamic Cultural Center has physical and non-physical facilities. Its physical facilities consist of library, multipurpose rooms, bookstore and publishing, and the most important is Hussainiyah. And, the non-physical facilities are the official websites and other media which include the consultative facilities for the congregations to reach the faqih through ICC official website (icc-jakarta.com). These facilities become the support for Shiite knowledge introductions to whoever wants to learn.

The library is one of the most favourite destinations in the ICC to learn more about Shiism, from students who look for literature about Iran to those who want to learn more about Shia Islam in particular. Even though the majority of the books are Shiite books, Sunni books are also available as well as researches (bachelor and master's degree thesis) about Iran and Shia, and Iran as a country. These literatures are also available in Indonesian, Persian, and Arabic languages. Another facility is films that can be borrowed. Additionally, there are also Iranian movies the visitor can watch for free. However, the films are unable to be taken home for borrowing.

Besides the library, upstairs, there is a large multifunctional room where events and classes usually being held. Some rooms are complementing the existence of the room of other purposes. In an interview, Hafidh Alkaf said that ICC has several classes about Islamic Twelver Shiite - education such as jurisprudence, belief, Islamic thinking, Islamic logic, and irfan - Shiite Sufism (Alkaf, 2018). In one occasion, the researcher was granted a permission to observe a discussion of Jurisprudence at Hussainiyah. The discussion was attended by several middle age men led by the mujtahid. For one of the participant who frequently participates in the discussion, Hamka, classes like religious logic, mysticism, and jurisprudence are important for the follower of Ahlul Bayt. (Hamka, 2018)

Apart from the main building, a bookstore Nur al-Huda opens to serve people every day. The bookstore mainly sells Shiite books which are translated from Persian, but visitor can also find turbah, a rock which is used for prayer. Move further inside the ICC complex, there is a small corner that opens every special occasion to sell discounted books and other promotions.

The most important physical facilities perhaps is Hussainiyah. A Hussainiyah is a place that was built with the aim for public interests, such as respecting the death of Hussein ibn Ali. Most of the time, this particular hall is used for many kind of religious and non-religious occasions. It is opens for people who want to pray. And on Friday, the Friday prayer is held in this large room. A prayer that may distinguish a Shiite from Sunnis, notably, some gestures during the standings, prostrations and sittings. But it is not closed for the Sunni visitors. During the Ramadan, Hussainiyah is also used for special events. Iftar is regularly held here after the afternoon Quranic recitation and discussions. And during the Lailat-al-Qadar - 19th, 21st, and 23rd night of Ramadan, the room is used for Quran and Jawshan Kabir - a prayer believed to be answered during these nights - recitations. In important events, the mujtahid leads the celebration.

Not only physical facilities, ICC also provides non-physical facilities on its official website at icc-jakarta.com. This site gives articles about Islam and ICC. There are some menu selections such as 'Islam', 'Maarif Islam' (Islamic Knowledge), 'Info', 'Konsultasi' (Consultation), 'Tanya Jawab' (Questions and Answer), 'Tokoh (Figure)', 'Mozaik (Mozaic)', 'Opini (Opinion)', 'Wawancara (Interviews)', and 'Galeri (Galery)'. All of those menu consist of articles for anyone who is interested on learning Shiite. Moreover, the Questions and answer, people can ask anything about their issues to the mujtahid.

This identity policies conducted by Iran has managed to introduce the Iranian Shia Islam for Indonesian public. From the observations and interviews, the ICC has been already supported with sufficient physical or cyber facilities. These facilities are also free to be used 
by anyone who wants to visit the ICC. However, also from the observation, ICC still have most Shiite visitors compare to non-Shiites.

\subsection{ICC and Indonesian Public}

The existence of Shia Islam in Indonesia disputably has been in the archipelago far before the Iranian Revolution. Shiism in Indonesia is claimed that it has entered Indonesia during the time of Islamic Kingdoms. This argument was stated by M. Yunus Jamil and Hasymi, and Onggang Parlindungan who wrote a book entitled "Tuanku Rao" or "My Lord of Rao" (Zainuddin., dkk, 2000: 9-12). However, this argument is doubted by Azyumardi Azra who see their writings are groundless and irrelevant by relying on unreliable sources. He added that the political contestation that they wrote had not been happened in the time of Samudra-Pasai as stated by M. Yunus Jamil and Hasymi (Zainuddin dkk, 2000:12-15). With his stronger, scientifically, argument, Azra quoted from Von Rankel (1914) that the festivals that resembles Shiite festivals in Indonesia is no more than excitement without any ideological or political aspect that coincidentally resemble Shiite festivity as common knowledge.

Before the ICC was established in Jakarta, the understanding of Shiite Islam had been flourished far before it. There are different opinions about when the Shiism really entered Indonesia. These opinions argue verily from those who say that the Sultanate of Perak was a Shiite sultanate, to those who say that Shiism really entered Indonesia after the Iranian Revolution of 1979.

Despite of rejections from Indonesians communities, Shiites developed in the middle of society. Starting from 1990s, foundations and communities started to spread across the country. The existence of these organisations forced them to establish an organisation as a place for consolidation from all Ahlul Bayt communities in Indonesia (Hidayat, 2018).

And in 2003, the missionaries and clerics of Ahlul Bayt held the first national convention of Ahlul Bait Indonesia in Yogyakarta. Several meetings were also held in the following years in Purwokerto, Bogor, Malang and Jakarta in 2010 (Hidayat, 2018). And in the national convention in Jakarta, which was held at Asrama Haji Pondok Gede, the entire participants agreed to establish an organisation. Thus Ahlul Bait Indonesia was established as an organisation by 2010. (Hidayat, 2018)

The general Shiite Indonesians, and Ahlul Bait Indonesia in particular, regards the Islamic Cultural Center as the grace from God. Prior to the ICC's establishment, Najaf in Iraq or Qom in Iran are two cities where Shiites can learn the scholarly works more, as well as contacting the marja (Hidayat, 2018). Besides the Shiism, the existence of ICC is also regarded can give further information about Iran that is probably hard to find anywhere else. ICC is also regarded as the most authoritative to held Islamic events and celebrations - particularly Twelver Shia. In the other hand, ICC also helps to introduce Iran to students who want to study in Iran.

A Shiite person is required to follow his marja as their referee in any religious affairs. For Ahmad Hidayat, religion cannot be guessed (Hidayat, 2018). So, below the level of marja, a mujtahid who could not be a referee yet, is permitted to be questioned and asked for his opinion because he is the one who is already able to interpret the teaching for him. As mentioned before, the ICC director is a mujtahid, designated to be somebody to be questioned and asked for his opinion, especially for the Shiites in Indonesia who have to perform taqlid.

From ABI perspective, ICC does not only give benefits for the Shiites, but also to whomever and any organisation may get the advantage of ICC as a place of Islamic studies. Beside ABI, mainstream Sunni organisations such as Muhammadiyah and Nahdlatul Ulama 
have also had events together with ICC (Hidayat, 2018). The events may include religious event, seminars, or educations. (Alkaf, 2018)

Some events were held by Ahlul Bait Indonesia, using the facilities in the Islamic Cultural Center, between May and June 2018. One is a seminar remembering the birth of Imam Mahdi, and the other is a pesantren kilat - a short term boarding education for youth. The seminar was held on Saturday, 5th May 2018. The seminar was started with the discussion about religious teachings in the world related to peace. After that session, the discussion continues into environmental destruction. These phenomena were then linked with Imam Mahdi who will come with justice. Along with ABI, the seminar was held with the ICC, Pusat Kajian Peradaban Baru Islam - Centre of New Islamic Civilisation, and Komunitas Keberagaman (Peace Leader Indonesia) in remembrance the birth of Imam Mahdi (Ahlul Bait Indonesia). Meanwhile, the Pesantren Kilat was aimed for youth and was held between 5th to 8th June 2018. This event was participated by 54 people. The purpose of the event was building the Ahlul Bayt youth to be more advanced and be able to implement the values of the Mahdi. This occasion's agenda was Quranic recitation, talks, watching a film about Imam Mahdi, and activities welcoming the night of Lailat-al-Qadr. (Ahlul Bait Indonesia, Juni 2018)

So, Ahlul Bait Indonesia is one organisation for the Shiites in Indonesia that regard the ICC as one of the gift for them. Before the ICC establishment, knowledge about Twelver Shiites was only collected from literature sources. And if someone wanted to consult about Islamic law, he must refer to a mujtahid or marja who live in Iran or other countries. Here, ICC has been becoming the place for people to ask for laws and conducting events by ABI. Consequently, ABI can be regarded as an organisation that becomes ICC's objective of its existence.

Nonetheless, in another perspective, ICC is seemed to be more emphasised in fulfilling the Indonesian Shiites religious needs instead of introducing Iranian Islam for all Indonesian as a whole. It is probably understandable that Indonesian Shiite communities are those who need the existence of the institution in the first place. Whereas the marja' or mujtahid are not as important as individual religious understanding in Sunni Islam.

\section{DISCUSSION}

From the International Relations studies point of view, Islamic Cultural Center Jakarta is a foreign public diplomacy institution that introduces and celebrates Iranian Islamic festivities and knowledge. ICC, as an organisation, manifests Iranian constitution through introductions of Iranian Islamic culture. Next, as an institution, ICC has been becoming an intermediary or facilitator of knowledge transference between Iran and Indonesian public with its facilities, publication, and events. And in its relation with the Indonesian public, ICC, in larger extent, is utilised maximally by the Shiite community in Indonesia, and particularly Jakarta. Therefore, this institution is still in its halfway from its fundamental purpose.

Firstly, in spite of its position under the Embassy of Islamic Republic of Iran in Indonesia, Islamic Cultural Center operates under the Office of Supreme Leader. The embassy which is under the Ministry of Foreign Affairs or Iran plays a very minor role in ICC's managerial organisation. This situation may distinguish it the most, from any other foreign public diplomacy in Indonesia such as @america.

Since its opening in 2000, ICC has been directly managed by the Office of Supreme Leader. This situation happens due to Iranian constitution that separates the authorities between the supreme leader and the executive body of the government. This might be effective for the case of Iran. The division of power is clear and each could focus on managing 
their responsibility very well. It is shown by increasing numbers of visitors during the night of Shiite ritualistic commemoration and Iranian embassy still conducts their business without interference on Islamic related issues. Iranian embassy in the other hand frequently organise film festivals, but unrelated to Islamic issues and teachings.

This situation may be different from American public diplomacy in Indonesia. The United States of America introduce a friendly and fun America by opening a public diplomacy institution, @america (at America). In contrary with ICC, @america is directly under the Cultural Attaché both organisationally and managerially. There are also slightly different mission characteristic between these institutions. The US convey a transfer of image while Iran conveys more a transfer of Shiite Islamic knowledge.

Secondly, continuing the discussion in previous paragraph, Islamic Cultural Center Jakarta with its aim to introduce Iranian Twelver Shia Islam to Indonesian public is attributed with literatures, facilities, publication and Shiite-related events. This well-provided institution is able to educate the Indonesian public who visit and want to learn about Shiite Islam. Moreover, commemoration of Ali, Fatimah, and the Twelve Imams are regular events in the ICC. These events are part of festival introduction to Indonesian public. Through activities above, ICC is actually well-designed in cultural transference from Iran to Indonesia.

Thirdly, back to the purpose of ICC establishment, ICC was established to introduce Iranian Islamic Culture to the Indonesian public. In this case, they have been trying to hold an event along with local institution such as Ahlul Bait Indonesia or some universities. ICC also becomes the place for Shiite Muslims to seek for advice in religious matters. They also regularly held a seminar and classes for public to understand more about Iranian Islam. However, ICC is not widely exposed amongst Indonesians, except for Shiites, in Jakarta. Many of ICC visitors are belong to the Shiite denomination of Islam. Some we can find Sunnis during the day, mainly looking for literature for papers and assignments. But they are obviously outnumbered by the Shiites. Therefore, the aim is still not fully accomplished.

\section{CONCLUSION}

Encompassing concept of new public diplomacy, faith diplomacy and the theory of cultural public diplomacy, there are three main answers regarding the existence of ICC in Jakarta. First, the situation where ICC is subordinated the Embassy of Iran yet managerial affairs is conducted by the office of Supreme Leader is in accordance with constitutions. And it affected the form of public diplomacy. Second, relations between Shia Islam and ICC covers through its facilities and events. Third, ICC provide its facilities for the Shiite communities in Jakarta. Therefore, the Iranian public diplomacy in Indonesia is aimed mainly for the Shiites, but not closed for others.

As what have been explained above, Islamic Cultural Center Jakarta has a unique managerial structure. Structurally, this Iranian cultural centre is under the Embassy of the Islamic Republic of Iran. Yet, the management of the institution is directly guided under the Office of Supreme Leader. This situation can be understood that Iran emphasise Islam in its Public Diplomacy to Indonesia. With that purpose, the Iranian public diplomacy cannot be separated from Islam as its values. ICC is an extension of Iran as the actor who conduct the Public Diplomacy. ICC becomes the facilitator between Iranian Islamic Culture and Indonesian public. This corresponds the concept of new public diplomacy by Nicholas Cull, that the actor acts as facilitator for information exchange, and having an aim for a better relationship. (Cull, 2009:14) 
The Twelver Shia becomes an Important values in Iranian Public Diplomacy with Indonesia. This manifested from its facilities and events. This is in accordance with the concept of public diplomacy of Nicholas Cull, faith diplomacy of Mohammed el-Nawawy, and cultural public diplomacy theory developed by Nicholas Cull. The Iranian Islamic culture is reflected through ICC's events and facilities. Using these concepts and theories, cultural diplomacy is the actor's attempt to conduct in international community by making its cultural sources and achievements known outside of its country and facilitates the cultural transmissions (Cull, 2009:19). In ICC, the culture is introduced through library and many events within the ICC, and Hussainiyah as the place of Islamic introduction. The religious events held in ICC are also related with the school of thoughts. And Hussainiyyah is a place for people to conduct prayer or in some occasions, used for events.

Books published by ICC are also one of manifest of Twelver Shia through translated books from Persian into Indonesian. Some of this books may include: "Khalifah dan Imamah" that was translated from "Ghadir" by Ayatullah Baqir al-Shadr et al.; "Fisika Salat" that was translated from "Ahkam ven Ruh-e Namaz" by Muhammad Wahidi; and "Koleksi Amalan Mustajab: Tuntunan Ahlulbait Nabi SAW" that was translated from "Mafatih al-Jinan" by Sheikh Abbas Qommi. The information about the books is also available in the website.

Moreover, events in ICC is primarily related to Twelver Shiita. This events can be categorised into two category, regular and irregular. Regular classes of jurisprudence, mysticism, logic, etc. are aimed to introduce Iranian Islam to the public. In the other hand, the irregular events are seminars and religious celebrations.

In relations with the Shiite communities in Indonesia, Iran conducts its public diplomacy as the facilitator for religious purposes to the Shiites, and particularly to Ahlul Bait Indonesia. In accordance with public diplomacy concept of Iran, ICC uses smart power. The use of technology also put it into the category of new public diplomacy. The transfer of Iranian Islamic Culture is also manifested from its events and supported by its facilities.

\section{ACKNOWLEDGEMENT}

This research based on grant scheme of PITTA (Publikasi International Terindeks untuk Tugas Akhir) or also known as Indexed International Publications for Final Projects toward Universitas Indonesia students.

\section{REFERENCES}

[1]. Ad-Dimashqiyah, A. R., As-Salafi, A.I.M., Al-Kharashi, S. I. S. (2014).Shi'ism Exposed: an Analytical Exposition of the Shi'ah Belief from Their Original Sources. Petaling Jaya: Dakwah Corner Publication

[2]. Brinkmann, S. (2008). Interviewing. Dalam Given, L.M (2008). The SAGE Encyclopedia of Qualitative Methods. Thousand Oaks: Sage Productions.

[3]. Cook, K.E. (2008). In-Depth Interview. Dalam Given, L.M (2008). The SAGE Encyclopedia of Qualitative Methods. Thousand Oaks: Sage Productions.

[4]. Cull, N. (2009).Public Diplomacy: Lessons from the Past. Los Angeles: Figuroa Press.

[5]. Djelantik, S. (2008).Diplomasi: antara Teori dan Politik. Yogyakarta: Graha Ilmu

[6]. El-Nawawy, M. (2013).Muslims' Online Public Diplomacy. Dalam Seib, P. (2013) Religion and Public Diplomacy: Global Public Diplomacy (pp. 113-133). New York: Palgrave Macmillan 
[7]. Loskota, B. dan Flory.R. (2013). Why Religion Still Matters in the World. Dalam Seib, P. (2013) Religion and Public Diplomacy: Global Public Diplomacy (pp. 9-25). New York: Palgrave Macmillan.

[8]. Mujaheri, M. (1983). Islamic Revolution Future Path of the Nations. The External Liaison Section of the Central Office of Jihad-e-Sazandegi.

[9]. Qommi, A. (2018). Mafatih al-Jinan. Trans. Syamsul Arif dan Tim al-Huda. Koleksi Amalan Mustajab: Tuntunan Ahlul Bait Nabi SAW. Jakarta: Nur al-Huda

[10]. Sihbudi, R (1996), Biografi Politik Imam Khomeini, Jakarta: Gramedia Pustaka

[11]. SJ, F. dan Halim, A. (2012).Politik Islam Syiah:Imamah hingga Wilayah Faqih. Malang: UIN-Maliki Press

[12]. Tim Ahlul Bait Indonesia (2013). Buku Putih Mazhab Syiah, Jakarta: Dewan Pengurus Pusat Ahlul Bait Indonesia.

[13]. Tim Ahlul Bait Indonesia (2014).Syiah menurut Syiah. Jakarta: Dewan Pengurus Pusat Ahlul Bait Indonesia

[14]. Tim Riset Majelis Tinggi Urusan Islam Mesir (2015). Silsilah al-Mawsu'ah alIslamiyyah al-Mutakhashshihah: Mausu'ah al-Firaq wa al-Madzahib fi al-'Alam alIslami. Trans. Masturi Irham, Muhammad Abidun Zuhdi, Khalifaturrahman Fath. Ensiklopedi Aliran dan Madzhab di Dunia Islam. Jakarta: Pustaka Al-Kautsar.

[15]. Zadeh, M.H.F. (2017). Omuszaye Ahkom-Sathe Mutawasit. Terj. Emi Nurhayati. Fikih Praktis untuk Pemula. Jakarta: Nur Al-Huda.

[16]. Evans, A. \& Stevens D. (2010). "Towards Theory of Influence for Twenty-First Century Foreign Policy: the New Public Diplomacy in a Globalized World". Place Building and Public Diplomacy.Macmillan Publishers Ltd. 6(1).p. 18-26

[17]. Alkaf, A.H. (Juni, 2018). Cleric with Direct Mandate to be Interviewed by the Director, Personal Interview

[18]. Hamka - nama disamarkan, (Juni, 2018). ICC Visitor. Personal Interview

[19]. Hidayat, A. (Juni, 2018). General Secretary of Ahlul Bait Indonesia. Personal Interview

[20]. Embassy of Islamic Republic of Iran (2018). Home. Ministry of Foreign Affairs. $<$ http://jakarta.mfa.ir/index.aspx?fkeyid=\&siteid=223\&pageid=7116>

[21]. Islamic Cultural Center Jakarta (2018). <https://icc-jakarta.com/>

[22]. Islamic Republic of Iran (2017). Constitution. Ministry of Foreign Affairs. <http://en.mfa.ir/index.aspx?siteid=3\&pageid=2144>

[23]. The Office of the Supreme Leader (2010) In Law: Leadership in the Constitution of the Islamic Republic of Iran. The Office of Supreme Leader. <http://www.leader.ir/en/law? 